The Federal Reserve BANK of Kansas City ECONOMIC RESEARCH DEPARTMENT

The Performance of Monetary and Fiscal Rules in an Open Economy with Imperfect Capital Mobility

Marcela Meirelles Aurelio

January 2005

RWP 05-0I 


\title{
The Performance of Monetary and Fiscal Rules in an Open ECONOMY WITH IMPERFECT CAPITAL MOBILITY
}

\author{
Marcela Meirelles Aurelio* \\ January 2005 \\ RWP 05-01
}

\begin{abstract}
This paper studies monetary and fiscal policy rules, and investigates the characteristics of optimal policies. The central focus of the paper is on the comparison of two types of fiscal rules: a balanced budget and a target for the primary surplus. Balanced budget rules (or, more generally, numeric ceilings to the overall budget deficit) are criticized because they may dictate higher taxes in periods of weak economic activity. The primary surplus rule, in contrast, has a less pro-cyclical nature, given that it does not require higher fiscal austerity in periods when the cost of servicing public debt is higher. In a nutshell, it allows a higher degree of tax smoothing. It is not clear, however, if (inevitable) fiscal adjustments should be postponed. These issues are investigated in the context of a dynamic stochastic general equilibrium model that describes an open economy, with capital accumulation, and where nominal rigidities are present. The model shows that previous findings drawn from open economy models - in particular with respect to the characteristics of optimal monetary policy-do not hold once the implications of certain fiscal regimes are taken into account, and once different scenarios concerning the degree of capital mobility are considered. The model is calibrated and simulated for the case of Brazil, a country that since 1999 has targets for inflation and for the primary surplus. The main finding is that a fiscal regime characterized by a target for the primary surplus delivers superior economic performance, a property captured by the shape of the efficient policy frontier.
\end{abstract}

Keywords: Fiscal and monetary policy rules, distortionary taxation, inflation target

JEL classification: E5, E6, F4, H3, H6

\footnotetext{
* Marcela Meirelles Aurelio is an economist at the Federal Reserve Bank of Kansas City. The author is grateful to Sebastian Edwards for his guidance and encouragement. The author also benefited from discussions with Sharon Kozicki, Monika Piazzesi, Lee Ohanian and Carlos Végh, as well as seminar participants at the Economics Department of UCLA, the Economic Research Department of the Federal Reserve Bank of Kansas City, and at the $8^{\text {th }}$ Annual Meeting of LACEA. The views expressed herein are solely those of the author and do not necessarily reflect the views of the Federal Reserve Bank of Kansas City or the Federal Reserve System.
}

Meirelles Aurelio email: marcela.meirelles.aurelio@kc.frb.org 


\section{Introduction}

Policy rules are a popular way to describe, and in some cases, to actually implement macroeconomic policy. Fiscal rules, in particular, became a commonly used device to enforce fiscal discipline. However, these rules are subject to criticism, especially if they dictate lower spending or higher taxes without taking into consideration cyclical economic conditions. As a consequence, many people argue that less stringent rules should be adopted. ${ }^{1}$

When it comes to discussing monetary policy rules, in turn, there seems to be a consensus: researchers have shown, and many policymakers accept the idea that it is optimal to have small inflation volatility, even if this implies a strong response, in terms of higher interest rates. ${ }^{2}$

A relevant question, then, is: what are the implications of a policy mix that incorporates the two policy recommendations: strict targets for the performance of fiscal accounts and low tolerance with respect to inflation? A restrictive monetary policy increases the interest cost of outstanding public debt, and potentially decreases the tax base. In this context, rules that establish numeric ceilings for the overall budget deficit can be hard to be fulfilled. Canzoneri, Cumby and Diba (2004) provide an insightful way to think about this problem: "Rules like the [Stability and Growth Pact] do not simply force Governments to stabilize their fiscal policies; they force national fiscal policies to respond to movements in the deficit to GDP ratio that come primarily from other sources". In this paper I show that, indeed, this is not optimal.

The goal of this research is to provide a deeper understanding of the consequences of policy rules and answer the question of why (and when) a certain policy rule configuration might be preferred over another. This issue is addressed with a dynamic stochastic general equilibrium model that describes a small open economy, with capital accumulation, and where nominal rigidities are present.

The central focus is on the consequences of different fiscal rules. It is assumed that the Monetary Authority adjusts the nominal interest rate according to a Taylor Rule ${ }^{3}$ and then two different scenarios for fiscal rules are examined: a balanced budget and a primary surplus target.

One important issue in the literature on fiscal and monetary policy rules is whether these rules are compatible with the existence of a unique and stable equilibrium. Leeper (1991), Leith and WrenLewis (2000), Bénassy (2003) and Annicchiarico, Marini and Piergallini (2004), among others, study

\footnotetext{
${ }^{1}$ A good example was the debate concerning the rules of the Stability and Growth Pact sealed among members of the European Monetary Union. It established that the public deficit could not be larger than 3\% of GDP. Critics argued that a more appropriate rule would be to set the size of the primary balance in accordance to the size of the stock of debt. See, for example, Canzoneri, Cumby and Diba (2002).

${ }^{2}$ See, for instance, Goodfriend and King (1997), King and Wolmann (1999) and Rotemberg and Woodford (1999). Erceg, Henderson and Levin (2000) show that conclusions change when wages are also sticky (in a nutshell, the trade-off between inflation and output variance is again a feature of the model).

${ }^{3}$ For a detailed discussion, please refer to Taylor (1993).
} 
the properties of equilibrium in the presence of fiscal/monetary rules. These policy reaction functions, in turn, are used to classify policies as active or passive. " For instance, fiscal policies are "passive" when the primary surplus is endogenous, in the sense that it adjusts to ensure fiscal solvency, given the equilibrium path of prices pinned down by monetary policy. Equilibrium determinacy and stability can also arise when monetary policy is passive and fiscal policy is active, in which case the primary surplus does not respond sufficiently enough to increases in the stock of public debt.

In the model employed in this paper, the combination of passive fiscal policy and active monetary policy renders the existence of a unique and stable equilibrium. The objective, therefore, is not a general study of policy combinations and the associated characteristics of equilibrium, but a deeper understanding of the implications of distinct fiscal regimes, within the class of passive fiscal policies. This goal will be achieved by comparing the implications of a balanced budget rule and a primary surplus target rule to equilibrium allocations, and by examining how they affect the characteristics of optimal monetary policy rules.

In terms of the existing literature on optimal fiscal and monetary policy in the presence of nominal rigidities and distortionary taxation, this research is related to Kollman (2004), Schmitt-Grohé and Uribe (2004a) and Siu (2004)..$^{5}$ This paper contributes to this literature in two different directions.

Siu (2004) shows that the optimal degree of tax smoothing depends on the size of Government spending shocks. As these shocks get larger, it is optimal to reduce tax volatility and let inflation be a shock absorber, decreasing the real value of Government liabilities. Instead of focusing on the size of the shock, I argue that the nature of the shock plays an important role when it comes to understanding differences in the path of distortionary taxes, implied by different fiscal regimes.

Schmitt-Grohé and Uribe (2004a) and Kollman (2004) study optimal fiscal and monetary policy rules in a closed economy, sticky prices model. One of their conclusions is that optimal monetary policy features a muted response to output.

The model employed in this paper yields a different conclusion: optimal monetary policy involves a quite strong response with respect to output fluctuations. This is a typical result of open economy models with nominal rigidities and high degree of pass-through from the exchange rate to inflation. However, the model shows that this also depends on the degree of capital mobility, which plays an important role in the determination of the optimal policy parameters.

I find that, as economies get closer to the "closed economy" paradigm, the influence of high pass-through on optimality conditions (not surprisingly) decreases. Results are again more in line with Schmitt-Grohé and Uribe (2004), i.e. a more muted response to output fluctuations is optimal. The interesting finding, however, is that this result also depends on the specific type of fiscal rule being examined, not being verified, for instance, in the case of an economy whose fiscal policy is

\footnotetext{
${ }^{4}$ This terminology was introduced by Leeper (1991).

${ }^{5}$ Other important references are Correia, Nicolini and Teles (2002) Schmitt-Grohé and Uribe (2004b).
} 
characterized by a primary surplus target.

The main result of the paper is that, using as benchmark a loss function whose parameters are the unconditional variance of inflation and output, then a primary surplus target rule is optimal, compared to a balanced budget rule. However, this result holds only if, in the event of an increase of the stock of public liabilities, the Fiscal Authority responds by raising sufficiently enough the target for the primary surplus. In other words, even though some degree of tax smoothing is desirable, the overall conclusion is that fiscal adjustments should not be significantly delayed.

Does this mean that advocates of more stringent fiscal rules (that set ceilings to the overall budget balance) are simply providing bad advice? Maybe not. The reason is that if we consider a class of fiscal rules that are really comparable (in the sense that they share the same nonstochastic steady state), and that do not violate the solvency condition of the Government, then one interesting conclusion is that it is not always the case that different rules will trigger substantially different time paths for taxation. In a nutshell, the nature of stochastic shocks matter, since they have different implications for the fiscal accounts.

When it comes to modelling exogenous disturbances, the literature focused on generic "costpush" shocks. In this paper, a different approach is taken. The model explores the role of a shock that increases inflation through its effect on the nominal exchange rate. More specifically, it is assumed that the economy faces country risk premium shocks, which trigger sudden exchange rate depreciation.

The introduction of this feature is common in open economy models that study the effect of monetary policy in the presence of price stickiness. An advantage of this modelling strategy is that most economies that explicitly announced fiscal rules are frequently subject to volatile capital flows and sudden changes in the country risk premium charged in foreign loans. Not surprisingly, the adoption of fiscal rules became an important clause of agreements with the International Monetary Fund, especially after these economies experienced capital flow reversals.

The paper is structured as follows. The first section lays out the economic environment. Then, the technique used to solve the model numerically and parameter choices are described. The model is calibrated and simulated to the case of the Brazilian economy and the dynamic adjustment of the economy is analyzed. In the final section, the general findings of the paper and directions for future research are discussed. 


\section{Analytical Framework}

The framework shares features with Kollman (2002), who also examines an open economy subject to imperfect capital mobility, given by the presence of debt-elastic interest rate on foreign loans. Like in Devereux, Lane and Xu (2004), I also develop a model in which the nontradable sector is the one subject to imperfect competition. These two models do not investigate the issue of optimal fiscal policy. They have, on the other hand, a more elaborate production structure, both in the tradables and nontradables sector. For instance, they explore the distinction between intermediate and final goods production, and allow for deviations in the Law of One Price.

The strategy adopted here was to simplify the production/pricing structure, in order to make room for a more straightforward interpretation of the differences in dynamic adjustment to shocks, under different fiscal regimes.

\subsection{Households}

Households are endowed with a constant, nonstorable amount of tradable goods $Y^{T}$ every period. They consume tradables $\left(C^{T}\right)$ and nontradable goods $\left(C^{H}\right)$, and the consumption index is given by:

$$
C_{t}=\left(C_{t}^{T}\right)^{\alpha}\left(C_{t}^{H}\right)^{1-\alpha}
$$

Let $P_{t}^{T}$ and $P_{t}^{H}$ denote the domestic price of tradable goods and nontradable goods, respectively. Then the consumption price index will be:

$$
P_{t}=\left(P_{t}^{T}\right)^{\alpha}\left(P_{t}^{H}\right)^{1-\alpha}
$$

Optimal shares of consumption of tradables and nontradables are given by: ${ }^{6}$

$$
\begin{gathered}
C_{t}^{T}=\alpha \frac{P_{t}}{P_{t}^{T}} C_{t} . \\
C^{H}=(1-\alpha) \frac{P_{t}}{P_{t}^{H}} C_{t} .
\end{gathered}
$$

Define the real exchange rate as:

$$
e_{t}=\frac{P_{t}^{T}}{P_{t}^{H}} .
$$

\footnotetext{
${ }^{6}$ Both the functional form of the consumer price index and the optimal level of consumption of each kind of good are discussed in Obstfeld and Rogoff (1998).
} 
The international price of the tradable good $P^{T^{*}}$ is constant and, without loss of generality, is equal to one. Let the nominal exchange rate be denoted by $S_{t}$, then:

$$
P_{t}^{T}=S_{t} P^{T^{*}} \Rightarrow e_{t}=\frac{S_{t}}{P_{t}^{H}}
$$

The nominal exchange rate depreciation in period $t$ is given by:

$$
\varepsilon_{t}=\frac{S_{t}}{S_{t-1}}
$$

Households lifetime utility is:

$$
U=E_{0} \sum_{t=0}^{\infty} \beta^{t}\left\{\frac{C_{t}^{1-\sigma}}{1-\sigma}-\frac{N_{t}^{1+\varphi}}{1+\varphi}\right\}
$$

Households buy tradable and nontradable goods. Part of nontradable good purchases is consumed and the remaining is invested (i.e., it becomes addition to the capital stock). One period later, this increase in the capital stock (plus undepreciated capital $\left.(1-\delta) K_{t}\right)$ is rented to nontradable goods producing firms. Households also decide how many hours to work $\left(N_{t}\right)$ at these firms. Capital income $\left(Q_{t}\right)$ and labor income $\left(W_{t}\right)$ are subject to taxation (at rates $\tau_{t}^{K}$ and $\tau_{t}^{W}$, respectively). Households own the nontradable good producing firms, and receive profits $\Pi_{t}$.

Households hold two types of bonds. One type of bond is issued by the Government, denominated in domestic currency $\left(B_{t}\right)$, and pays, one period later, the risk free gross return $\left(1+i_{t}\right)$. Households also hold internationally traded bonds $D_{t}^{p}$ denominated in units of the tradable good. Assume, without loss of generality, that households are net debtors in the external market, so $D_{t}^{p}$ is the amount of net external liabilities that matures one period later, paying the gross interest rate $\left(1+i_{t}^{F}\right)$. Finally, I assume the existence of a cash-in-advance constraint (always binding), where $M_{t}$ are nominal money balances:

$$
M_{t}=\gamma P_{t} C_{t}
$$

The budget constraint is:

$$
\begin{aligned}
& \frac{M_{t-1}}{P_{t}}+\left(1+i_{t-1}\right) \frac{B_{t-1}}{P_{t}}+\frac{P_{t}^{H}}{P_{t}} \Pi_{t}+\frac{S_{t}}{P_{t}} D_{t}^{p}+\frac{P_{t}^{T}}{P_{t}} Y_{t}^{T}+\left(1-\tau_{t}^{W}\right) \frac{W_{t}}{P_{t}} N_{t}+\left(1-\tau_{t}^{K}\right) \frac{Q_{t}}{P_{t}} K_{t-1} \\
\leq & C_{t}+\frac{M_{t}}{P_{t}}+\frac{B_{t}}{P_{t}}+\frac{P_{t}^{H}}{P_{t}}\left(K_{t}-(1-\delta) K_{t-1}\right)+\left(1+i_{t-1}^{F}\right) \frac{S_{t}}{P_{t}} D_{t-1}^{p} .
\end{aligned}
$$

Households maximize (8), given the optimal share of tradables and nontradables consumption (3) and (4), the initial stock of net assets and the cash in advance constraint. They cannot engage in Ponzi schemes and are subject to (10). 
Optimization requires that the following conditions hold (where $\lambda_{t}$ is the Lagrange multiplier of the flow budget constraint):

$C_{t}$ :

$$
\beta^{t}\left(C_{t}^{-\sigma}-(1+\gamma) \lambda_{t}\right)+\beta^{t+1} \gamma E_{t} \frac{\lambda_{t+1}}{1+\pi_{t+1}}=0
$$

$N_{t}$ :

$$
\beta^{t}\left(\lambda_{t}\left(1-\tau_{t}^{W}\right) \frac{W_{t}}{P_{t}}-N_{t}^{\varphi}\right)=0
$$

$B_{t}:$

$$
-\beta^{t} \frac{\lambda_{t}}{P_{t}}+\beta^{t+1} E_{t} \lambda_{t+1} \frac{1+i_{t}}{P_{t+1}}=0
$$

$D_{t}^{p}:$

$$
\beta^{t} \lambda_{t} \frac{S_{t}}{P_{t}}-\beta^{t+1} E_{t} \lambda_{t+1}\left(1+i_{t}^{F}\right) \frac{S_{t+1}}{P_{t+1}}=0
$$

$K_{t}:$

$$
-\beta^{t} \lambda_{t} \frac{P_{t}^{H}}{P_{t}}+\beta^{t+1} E_{t} \lambda_{t+1}\left(\left(1-\tau_{t+1}^{K}\right) \frac{Q_{t+1}}{P_{t+1}}+\frac{P_{t+1}^{H}}{P_{t+1}}(1-\delta)\right)=0 .
$$

For ease of exposition, I assume that the covariance of the multiplier $\lambda_{t+1}$ with the one period marginal return on domestic and foreign bonds, and with the marginal return on capital are equal to zero. ${ }^{7} \mathrm{I}$ also assume that there is no inflation risk or currency risk. ${ }^{8}$ Then, it follows that:

$$
E_{t} \frac{1+i_{t}}{1+\pi_{t+1}}=e_{t}^{\alpha}\left[E_{t} X_{t+1}+(1-\delta) E_{t} e_{t+1}^{-\alpha}\right]
$$

where

$$
\begin{gathered}
X_{t+1}=\left(1-\tau_{t+1}^{K}\right) q_{t+1} \\
q_{t+1}=\frac{Q_{t+1}}{P_{t+1}} .
\end{gathered}
$$

It also follows that:

$$
E_{t} \frac{1+i_{t}}{1+\pi_{t+1}}=E_{t}\left(1+i_{t}^{F}\right)\left(\frac{1+\varepsilon_{t+1}}{1+\pi_{t+1}}\right)
$$

Given the assumption that the inflation risk premia for foreign and domestic bonds is zero, then (18) simplifies to the usual uncovered interest rate parity condition:

\footnotetext{
${ }^{7}$ It would suffice to assume that these covariances are constant, because they would vanish when variables are transformed to their percentage deviation from the steady state.

${ }^{8}$ The inflation risk is the covariance of nominal returns (in domestic currency) and expected inflation in $t+1$. The currency risk is the covariance of real returns (in foreign currency) and expected nominal exchange rate depreciation between $\mathrm{t}$ and $\mathrm{t}+1$.
} 


$$
1+i_{t}=E_{t}\left(1+i_{t}^{F}\right)\left(1+\varepsilon_{t+1}\right)
$$

Combining (11) and (13):

$$
\frac{U_{c_{t}}}{\lambda_{t}}=\frac{C_{t}^{-\sigma}}{\lambda_{t}}=1+\gamma \frac{i_{t}}{1+i_{t}}
$$

Then, (12) and (20) yield:

$$
\frac{U_{N_{t}}}{U_{c_{t}}}=\frac{N_{t}^{\varphi}}{C_{t}^{-\sigma}}=\frac{\left(1-\tau_{t}^{W}\right)}{1+\gamma \frac{i_{t}}{1+i_{t}}} \frac{W_{t}}{P_{t}}
$$

\subsection{Imperfect Capital Mobility}

The interest rate charged on foreign loans to domestic residents is equal to the world nominal rate $i^{*}$, plus a country risk premium that contains two components: an exogenous term $\xi$ and an endogenous component $\left(\frac{D_{t}}{D^{*}}\right)^{\kappa}$, which depends positively on the size of the economy's total net foreign liabilities with respect to an exogenous threshold $D^{*}$.

$$
\left(1+i_{t}^{F}\right)=\left(1+i^{*}\right)\left(1+\xi_{t}\right)\left(\frac{D_{t}}{D^{*}}\right)^{\kappa}
$$

Whenever $D_{t} \succ D^{*}$, the wedge between $i^{F}$ and $i^{*}$ will increase, depending on the elasticity $\kappa$. The exogenous component of the country risk premium follows an autoregressive process (in log deviations from the steady state $\bar{\xi}$ )

$$
\xi_{t}=\rho_{\xi} * \xi_{t-1}+\varepsilon_{\xi, t} \quad\left\{\varepsilon_{\xi, t}\right\}_{t=0}^{\infty} \sim i i d\left(0, \sigma_{\varepsilon_{g}}^{2}\right) .
$$

The assumption of an upward sloping supply of foreign funds is convenient because small open economy models pose the difficulty that they predict a non-stationary path for net foreign assets, a problem eliminated by the assumption of a debt-elastic interest rate. ${ }^{9}$ In addition, the presence of an upward sloping supply of funds may explain the stylized fact that many economies - emerging market economies in particular - face significant spreads with respect to the world interest rate when they borrow funds in the international market place.

\footnotetext{
${ }^{9}$ See Schmitt-Grohé and Uribe (2003).
} 


\section{$2.3 \quad$ Firms}

There is a continuum of firms, and each firm is a monopolistic producer of a particular variety of nontradable good (indexed by i, $i \in[0,1]$ ), facing a constant elasticity of demand $\phi$. Consumer preferences are such that demand faced by producer $i$ is given by:

$$
y_{t}^{H}(i)=\left(\frac{P_{t}^{H}(i)}{P_{t}^{H}}\right)^{-\phi} Y_{t}^{H}
$$

where

$$
\begin{aligned}
& y_{t}^{H}(i)=\text { demand for nontradable produced by firm } i \\
& Y_{t}^{H}=\text { aggregate nontradables demand; }{ }^{10} \\
& P_{t}^{H}(i)=\text { price charged by firm } i \\
& P_{t}^{H}=\text { nontradables aggregate price index. }
\end{aligned}
$$

I assume staggered prices à la Calvo (1983). At each point in time a fraction $(1-\psi)$ of the firms will set new prices. It has been shown ${ }^{11}$ that the price-setting decision will be dictated by the objective of achieving a mark-up over marginal costs that is, on average, as close as possible to the (constant) desired mark-up that would prevail if firms could reset prices every period. King and Wolman (1999) have shown that, in the presence of steady state inflation this desired mark-up is given by:

$$
\Phi=\frac{\phi}{1-\phi}\left(\frac{1+\left(1+\bar{\pi}^{H}\right)^{\phi-1}}{2}\right)^{\frac{1}{1-\phi}}\left(\frac{1+\beta\left(1+\bar{\pi}^{H}\right)^{\phi}}{1+\beta\left(1+\bar{\pi}^{H}\right)^{\phi-1}}\right) .
$$

A firm that resets the price at time $\mathrm{t}$ (and has it fixed for s-t, with probability $\psi^{s-t}$ ) chooses the optimal price $P_{t}^{*}(i)$ in order to maximize expected profits:

$$
\underset{P^{*}}{M a x} V_{t}=E_{t} \sum_{s=t}^{\infty}(\psi \beta)^{s-t} \lambda_{s}\left[P_{s}^{* H}(i) y_{s}^{H}(i)-T C_{s}\left(y_{s}^{H}(i)\right)\right]
$$

where the first term in the brackets are revenues and the second are total costs of firm $i$. Substituting

\footnotetext{
${ }^{10}$ In equilibrium, this is equal to the aggregate supply of nontradable goods $Y^{H}=\left[\int_{0}^{1} y h(i)^{\frac{\phi-1}{\phi}} d i\right]^{\frac{\phi}{1-\phi}}$

${ }^{11}$ See Goodfriend and King (1997).
} 
(24) in the maximization problem and taking first order condition with respect to $P^{*}$, we have: ${ }^{12}$

$$
0=E_{t} \sum_{s=t}^{\infty}(\psi \beta)^{s-t}\left[(1-\phi)\left(P_{t}^{* H}(i)\right)^{-\phi}\left(\frac{1}{P_{s}^{H}}\right)^{-\phi} Y_{s}^{H}+\phi M C_{s}(i)\left(P_{t}^{* H}(i)\right)^{-\phi-1}\left(\frac{1}{P_{s}^{H}}\right)^{-\phi} Y_{s}^{H}\right]
$$

where $M C_{s}(i)$ is the marginal costs of production faced by producer i at time s. This optimality condition yields the expression for $P_{t}^{* h}(i)$ :

$$
P_{t}^{*}(i)=\frac{\phi}{\phi-1} \frac{\sum_{s=t}^{\infty}(\psi \beta)^{s-t} M C_{s}(i) Y_{s}^{H}}{\sum_{s=t}^{\infty}(\psi \beta)^{s-t} Y_{s}^{H}} .
$$

The derivation of the New-Keynesian Phillips curve is based on a linearization of the expression (28) around the steady state. Typically, this is done assuming that steady state inflation is equal to zero. In order to incorporate the fact that it is assumed the existence of inflation in the steady state, some modifications must be made. Suppose that, in steady state, inflation in the nontradables sector is given by $\bar{\pi}_{t}^{H}$. Canzonneri (2002) shows that it suffices to redefine the steady state as one in which nontradable goods prices are indexed to the steady state $\bar{\pi}^{H}$. This means that even when prices are not reset, they are still "adjusted" by the steady state inflation index. Then the stationary prices and marginal cost are their detrended values. Taking these modifications into account, the equation that describes the evolution of inflation in the nontradable goods sector is:

$$
\pi_{t}^{h}=\beta E_{t} \pi_{t+1}^{h}+\chi r m c_{t}
$$

where $r m c$ is the log deviation of real marginal cost of production with respect to its "flexible price" level, and

$$
\chi=(1-\psi)(1-\beta \psi) / \psi .
$$

The expression for the economy's real marginal costs is model specific, in the sense that it will depend on assumptions concerning preferences and technology. I assume that each producer uses the same technology, described by ${ }^{13}$ :

$$
Y_{t(i)}^{h}=K_{t(i)}^{\theta} N_{t(i)}^{(1-\theta)}
$$

By definition, the real marginal cost $R M C_{t}$ is:

\footnotetext{
${ }^{12}$ In the expression below, $\lambda_{s}$ discounts expected flows realized (s-t) periods ahead.

${ }^{13}$ Here I denote $K_{t(i)}$ the amount of capital used in production at time t, by firm i. The equilibrium rental rate of capital $Q_{t}$ will depend on supply of capital (by assumption determined at t-1) and total demand of capital by firms. This means that in aggregate terms, and in equilibrium, $Y_{t}^{H}=K_{t-1}^{\theta} N_{t}^{1-\theta}$
} 


$$
R M C_{t}=\frac{1}{\Phi_{t}}=\frac{W_{t}}{P_{t}^{H} M P N_{t}}=\frac{Q_{t}}{P_{t}^{H} M P K_{t}}
$$

Equation (32) can be reinterpreted by using the household's optimality conditions. First notice that:

$$
\frac{W_{t}}{P_{t}}=\frac{W_{t}}{P_{t}^{H}} \frac{1}{e_{t}^{\alpha}}
$$

Then, using (21):

$$
\frac{N_{t}^{\varphi}}{C_{t}^{-\sigma}}=\frac{\left(1-\tau_{t}^{W}\right)}{1+\gamma \frac{i_{t}}{1+i_{t}}} \frac{W_{t}}{P_{t}^{H}} \frac{1}{e_{t}^{\alpha}} .
$$

Finally, we can relate this last expression to the real marginal cost:

$$
R M C_{t}=e_{t}^{\alpha} \frac{1}{M P N_{t}} \frac{1+\gamma \frac{i_{t}}{1+i_{t}}}{\left(1-\tau_{t}^{W}\right)} \frac{N_{t}^{\varphi}}{C_{t}^{-\sigma}}
$$

\subsection{Monetary Policy}

\subsubsection{Interest Rate Rule}

The Monetary Authority has an explicit target for annual CPI inflation, given by:

$$
\pi_{t}=\alpha \varepsilon_{t}+(1-\alpha) \pi_{t}^{H} .
$$

The nominal interest rate $i_{t}$ is the policy instrument, and is raised according to the following "Taylor Rule":

$$
\widehat{i}_{t}=\mu_{\pi} \widehat{\pi}_{t}+\mu_{y} \widehat{y}_{t}
$$

where

$$
\begin{gathered}
\widehat{i}_{t}=\log \left(1+i_{t}\right)-\log (1+\bar{i}) ; \\
\widehat{\pi}_{t}=\log \left(1+\pi_{t}\right)-\log \left(1+\pi^{*}\right) ; \\
\widehat{y}_{t}=\log y_{t}-\log \bar{y} .
\end{gathered}
$$

In the expressions above, $\bar{y}$ and $\bar{i}$ are the stationary values of gross domestic product and the nominal interest rate, respectively, and $\pi^{*}$ is the target for CPI inflation. 


\subsubsection{Money Growth}

The inflation target equals steady state inflation. For this assumption to be compatible with the existence of a stationary level of real money balances, it follows that money supply $M^{S}$ must be increasing at a rate equal to the inflation rate:

$$
M_{t+1}^{S}=\nu M_{t}^{S}
$$

In equilibrium, money supply equals money demand $\left(M^{S}=M^{D}=M\right)$. Moreover, the existence of a stationary level of money demand implies ${ }^{14}$ :

$$
\frac{M_{t+1}}{P_{t+1}}=\frac{M_{t}}{P_{t}} \Rightarrow \frac{M_{t+1}}{M_{t}}=\frac{P_{t+1}}{P_{t}}=\nu=\left(1+\pi^{*}\right)^{\frac{1}{4}} .
$$

\subsection{Fiscal Policy}

The Government flow budget constraint is:

$$
M_{t}-M_{t-1}+B_{t}+S_{t} D_{t}^{g}+T_{t}-P_{t}^{H} g_{t}=\left(1+i_{t-1}\right) B_{t-1}+\left(1+i_{t-1}^{F}\right) S_{t} D_{t-1}^{g}
$$

where

$g_{t}=$ government expenditure on nontradable goods;

$B_{t}=$ risk-free nominal one period domestic government bonds;

$D_{t}^{g}=$ Government foreign debt, measured in units of the tradable good;

$T_{t}=\tau_{t}^{W} W_{t}+\tau_{t}^{K} Q_{t}=$ nominal tax revenues.

The flow constraint says that public debt maturing at time $\mathrm{t}$ (principal plus interest) have to monetized $\left(M_{t}-M_{t-1}\right)$, rolled over $\left(B_{t}\right.$ and $\left.S_{t} D_{t}^{g}\right)$, or paid-off with a primary surplus $\left(T_{t}-P_{t}^{H} g_{t}\right)$. Let $\frac{T_{t}}{P_{t}}=t_{t}, m_{t}=\frac{M_{t}}{P_{t}}, b_{t}=\frac{B_{t}}{P_{t}}$, and use the definition (5) of the real exchange rate $e_{t}$ and of the price index (2). Then, in real terms, the budget constraint is:

$$
m_{t}+\frac{m_{t-1}}{1+\pi_{t}}+b_{t}+e_{t}^{1-\alpha} D_{t}^{g}+t_{t}-\frac{g_{t}}{e_{t}^{\alpha}}=\left(\frac{1+i_{t-1}}{1+\pi_{t}}\right) b_{t-1}+\left(1+i_{t-1}^{F}\right) e_{t}^{1-\alpha} D_{t-1}^{g} .
$$

Let $h$ be the total real amount of end of period government liabilities at time t:

$$
h_{t}=m_{t}+b_{t}+e_{t}^{1-\alpha} D_{t}^{g}
$$

\footnotetext{
${ }^{14}$ It is assumed that the each time period corresponds to a quarter, and that the inflation target is set in annual terms.
} 
The real primary surplus is:

$$
s_{t}=\frac{T_{t}}{P_{t}}-\frac{P_{t}^{H}}{P_{t}} g_{t}=t_{t}-\frac{g_{t}}{e_{t}^{\alpha}} .
$$

Define $R_{t}=\frac{1+i_{t-1}}{1+\pi_{t}}$, then using (40) and (41), the budget constraint (39) can be rewritten as:

$$
h_{t-1}=\frac{1}{R_{t}}\left(h_{t}+s_{t}-\left(\left(1+i_{t-1}^{F}\right) e_{t}^{1-\alpha}-\frac{1+i_{t-1}}{1+\pi_{t}} e_{t-1}^{1-\alpha}\right) D_{t-1}^{g}+\frac{i_{t-1}}{1+\pi_{t}} m_{t-1}\right) .
$$

Solving (42) forward, the No Ponzi Game Condition is:

$$
\lim _{T \rightarrow \infty} E_{t}\left(\frac{1}{R_{t, T}} h_{T}\right)=0
$$

Or equivalently,

$$
h_{0}=\sum_{j=0}^{\infty} E_{t} \frac{1}{R_{t, t+j}}\left(\frac{i_{t+j-1}}{1+\pi_{t+j}} m_{t+j-1}-\left(\left(1+i_{t+j-1}^{F}\right) e_{t+j}^{1-\alpha}-\frac{1+i_{t+j-1}}{1+\pi_{t+j}} e_{t+j-1}^{1-\alpha}\right) D_{t+j-1}^{g}+s_{t+j}\right),
$$

where

$$
E_{t}\left(\frac{1}{R_{t, t+j}}\right)=E_{t}\left(\frac{1}{R_{t}} \frac{1}{R_{t+1}} \ldots \frac{1}{R_{t+j}}\right) .
$$

Finally, the stochastic process followed by Government expenditures on nontradable goods (measured in log-deviations from its stationary level) is given by:

$$
g_{t}=\rho_{g} * g_{t-1}+\varepsilon_{g, t} \quad\left\{\varepsilon_{g, t}\right\}_{t=0}^{\infty} \sim i i d\left(0, \sigma_{\varepsilon_{g}}^{2}\right) .
$$

\section{Two Alternative Fiscal Regimes}

The common feature of the two fiscal regimes that will be considered is that adjustments rely on increased taxation. The two regimes, however, differ with respect to the degree with which the Fiscal Authority is willing to tolerate deviations from the stationary level of real Government liabilities $h^{*}$. In both scenarios, the following simplifying assumptions are adopted:

(i) The percentage changes in the tax distortions $\left(1-\tau_{t}^{W}\right)$ and $\left(1-\tau_{t}^{K}\right)$ are identical $^{15}$

(ii) The stock of Government foreign debt is kept constant. In other words, if a deficit is financed with a mix of higher taxes and bonds (case of the primary surplus rule), the Government increases

\footnotetext{
${ }^{15}$ Alternatively, the model could have been formulated using the assumption that a common tax rate $\tau$ incides on each type of income. Besides being more realistic, to allow for the existence of two different tax rates gives more flexibility when it comes to calibrating steady state values and trying to match empirical features.
} 
the supply of domestically traded, domestic currency denominated bonds, keeping $D^{g}$ constant. ${ }^{16}$ In order to match characteristics of the data, I further assume that the stationary level of foreign debt, measured in units of the composite good, is a certain fraction $a$ of the stationary level of domestic public debt, i.e., $\bar{e}^{1-\alpha} \bar{D}^{g}=a \bar{b}$

\subsection{A Balanced Budget}

Given exogenous Government expenditures $g_{t}$, the Fiscal Authority sets tax rates $\left\{\tau_{t}^{W}, \tau_{t}^{K}\right\}$ so that, at each point in time, the operational balance is equal to zero, so that:

$$
h_{t}=h_{t-1}=h^{*} \quad \text { for } \quad t \geqslant 1
$$

The Government seeks to keep constant the real value of end of period liabilities. It does so by levying enough taxes to pay for expenses on goods and real interest payments on the stock of outstanding debt.

\subsection{A Primary Surplus Target}

Consider, alternatively, the following rule. The Fiscal Authority sets tax rates in a way such that the real primary surplus corresponds to a fraction of the deviation of real Government liabilities maturing at time $\mathrm{t}$, with respect to the benchmark $h^{*}:{ }^{17}$

$$
s_{t}=\frac{T_{t}}{P_{t}}-\frac{P_{t}^{H}}{P_{t}} g_{t}=t_{t}-\frac{g_{t}}{e_{t}^{\alpha}}=\lambda_{0}+\lambda_{1}\left(h_{t-1}-h^{*}\right) .
$$

Note that, in a stationary steady state, the real primary surplus is equal to $\lambda_{0}$, which, in turn, is pinned down by the Government flow budget constraint, evaluated using the stationary levels of each variable. The stationary properties of the model are unchanged, and this allows explicit comparisons with the case of the balanced budget.

\footnotetext{
${ }^{16}$ The purpose of adopting this assumption is to make simpler the analysis of the dynamic adjustment. In this model, the level of net foreign assets has important implications for the exchange rate dynamics. If the Government foreign debt was allowed to vary, government spending shocks would have a direct impact on the level of net foreign liabilities, whereas if public external debt is kept constant, then the effect of the Government spending shock on the current account will be solely through the real exchange rate.

${ }^{17}$ Schmitt-Grohé and Uribe (2004) analyze a similar kind of rule and label it "liability targeting". The main difference is that they set tax revenues as a function of liabilities, whereas here the overall primary surplus is set as a function of liabilities. The implication is that balanced budget and liability targeting rules will trigger similar fiscal adjustments in the event of an unexpected increaes of Government purchases.
} 
Given the purposes of the present study, I restrict attention to policies in which $\lambda_{1}$ is strictly positive. Therefore, everything else equal, rule (48) does not allow the overall primary surplus to turn into a deficit in the event of an exogenous increase in government spending $g_{t}$. On the other hand, contrary to the case of a balanced budget, the primary balance may not rise sufficiently enough to pay-off increased real interest payments on maturing debt.

\subsection{Aggregate Resource Constraint}

To derive the aggregate resource constraint, use the definition that the aggregate nontradable output is either consumed by households or by the government:

$$
Y_{t}^{H}=g_{t}+C_{t}^{H}+I_{t} .
$$

Moreover, total revenues can be divided into total costs plus profits:

$$
P_{t}^{H}\left(g_{t}+C_{t}^{H}+I_{t}\right)=W_{t} N_{t}+Q_{t} K_{t-1}+\Pi_{t} .
$$

Using (3) and (4):

$$
P_{t}^{T} C_{t}^{T}+P_{t}^{H} C_{t}^{H}=P_{t}^{T} \alpha \frac{P_{t}}{P_{t}^{T}} C_{t}+P_{t}^{H}(1-\alpha) \frac{P_{t}}{P_{t}^{H}} C_{t}=P_{t} C_{t}
$$

Then, multiplying (10) by $P_{t}$ and using (50) and (51), then the household budget constraint can be rewritten as:

$$
M_{t-1}+\left(1+i_{t-1}\right) B_{t-1}+P_{t}^{T} Y^{T}+S_{t} D_{t}^{p}+P_{t}^{H} g_{t}-\tau_{t}^{W} W_{t} N_{t}-\tau_{t}^{K} Q_{t} K_{t-1}=P_{t}^{T} C_{t}^{T}+M_{t}+B_{t}+\left(1+i_{t-1}^{F}\right) S_{t} D_{t-1}^{p} .
$$

Combining (52) with the government flow constraint (38), the economy's flow resource constraint is derived (where $\left.D_{t}=D_{t}^{p}+D_{t}^{g}\right)$ :

$$
P_{T, t}\left(Y^{T}-C_{T, t}\right)+S_{t} D_{t}=\left(1+i_{t-1}^{F}\right) S_{t} D_{t-1}
$$

Since, by assumption, $P_{T, t}=S_{t} P_{T}^{*}=S_{t} \forall t$ then, the expression for the current account deficit simplifies to:

$$
D_{t}-D_{t-1}=C_{T, t}-Y^{T}+i_{t-1}^{F} D_{t-1}
$$

\subsection{Equilibrium}

Given the households initial stock of assets, tradable endowment, and the stochastic processes $\{\xi, g\}$, an (imperfectly) competitive equilibrium is an allocation $\left\{N, C^{H} ; C^{T} ; M ; D^{p} ; D^{g} ; B ; K\right\}$, a price system $\left\{i^{F}, P^{H} ; P^{T} ; S_{t} ; W_{t} ; Q_{t}\right\}$, and a Government policy $\left\{i, \tau^{K}, \tau^{W}, \pi^{*}\right\}$ such that: 
(1) Households maximize utility subject to constraints (9), (3), (4), (10), the initial asset position and the No-ponzi game condition.

(2) Firms maximize profits.

(3) Markets Clear:

(i) Nontradable goods market:

$Y^{H}=g+C^{H}+I$

(ii) Labor market:

$N^{S}=N^{D}$

(iii) Money market:

$M^{S}=M^{D}$

(iv) Domestic bonds market:

$B^{S}=B^{D}$

(v) Foreign loans market:

$D^{S}=D^{D}$

(by Walras Law the capital market is cleared).

(4) The Government No Ponzi condition is satisfied.

\section{Non-stochastic Stationary Equilibrium}

A stationary steady state equilibrium is characterized by CPI inflation that is equal to the targeted level $\left(\bar{\pi}^{c p i}=\pi^{*}\right)$, and optimal allocations are constant, in levels consistent with the equilibrium conditions of the model. I assume that the stationary tax rates on capital and labor income are exogenous policy variables, set by the Government. The stationary values of the other variables that enter the Government budget constraint are endogenously determined, and they pin down the steady state value of Government liabilities $h^{*}$. In the discussion that follows, a "bar" indicates stationary values.

Using the definition of the real exchange rate, then taking logs and first differences:

$$
e_{t}=e_{t-1}+\varepsilon_{t}-\pi_{t}^{h}
$$


In steady state, then, the rate of nominal exchange rate devaluation is equal to the inflation in the nontradables sector:

$$
\bar{e}=\bar{e}+\bar{\varepsilon}-\bar{\pi}^{h} .
$$

Log-linearizing the expression for the CPI index, we conclude:

$$
\pi_{t}^{c p i}=\alpha \varepsilon_{t}+(1-\alpha) \pi_{t}^{h}
$$

Then, using (56):

$$
\bar{\pi}^{c p i}=\pi^{*}=\bar{\varepsilon}=\bar{\pi}^{h} .
$$

Notice that (58) pins down the steady state optimal mark-up $\Phi$, given (25). Moreover, using (13), it is clear that a flat path for CPI inflation results in a flat path for the nominal interest rate:

$$
1+\bar{i}=\frac{1+\pi^{*}}{\beta}
$$

Second, in steady state the uncovered interest parity (18) (using the fact that $\pi^{*}=\bar{\varepsilon}$ ) results in:

$$
1+\bar{i}=\left(1+\bar{i}^{F}\right)\left(1+\pi^{*}\right)
$$

Therefore:

$$
1+\bar{i}^{F}=\frac{1+\bar{i}}{1+\pi^{*}}=\frac{1}{\beta}
$$

By definition,

$$
\left(1+\bar{i}^{F}\right)=\left(1+i^{*}\right)(1+\bar{\xi})\left(\frac{\bar{D}}{D^{*}}\right)^{\kappa}
$$

Assume that

$$
\left(1+i^{*}\right)(1+\bar{\xi})=\frac{1}{\beta}
$$

Then, since from (61) we know that $1+\bar{i}^{F}=\frac{1}{\beta}$ then the following relation must hold:

$$
\bar{D}=D^{*}
$$

The level of tradables consumption is:

$$
\bar{C}^{T}=Y^{T}-\frac{1-\beta}{\beta} \bar{D}
$$


The following 16 equations complete the description of the stationary equilibrium:

$$
\begin{aligned}
& \bar{m}=\gamma \bar{C} . \\
& \bar{C}=\left(\bar{C}^{T}\right)^{\alpha}\left(\bar{C}^{H}\right)^{1-\alpha} \text {. } \\
& \frac{\bar{C}^{H}}{\bar{C}^{T}}=\frac{1-\alpha}{\alpha} \bar{e} . \\
& \left(1-\bar{\tau}^{K}\right) \bar{q} \overline{e^{\alpha}}=\frac{1}{\beta}-(1-\delta) . \\
& \bar{q}=\frac{1}{\Phi} \theta \frac{1}{e^{\alpha}} \frac{\bar{Y}^{H}}{\bar{K}} . \\
& \bar{w}=\frac{1}{\Phi}(1-\theta) \frac{1}{\overline{e^{\alpha}}} \frac{\bar{Y}^{H}}{\bar{N}} . \\
& \bar{Y}_{N T}^{H}=\bar{K}^{\theta} \bar{N}^{1-\theta} \text {. } \\
& \bar{I}=\bar{K}-(1-\delta) \bar{K}=\delta \bar{K} \text {. } \\
& \bar{Y}^{H}=\bar{G}+\bar{C}^{H}+\bar{I} \text {. } \\
& \frac{\bar{N}^{\varphi}}{\bar{C}^{-\sigma}}=\frac{1-\theta}{\Phi} \frac{\left(1-\bar{\tau}^{W}\right)}{1+\gamma \frac{\bar{i}}{1+\bar{i}}} \frac{\bar{Y}^{H}}{\bar{N} \bar{e}^{\alpha}} \text {. } \\
& \frac{\bar{N}^{\varphi}}{\bar{\lambda}}=\left(1-\bar{\tau}^{W}\right) \bar{w} \text {. } \\
& \overline{\operatorname{tax}}=\bar{\tau}^{K} \bar{q}+\bar{\tau}^{W} \bar{w} . \\
& h^{*}=\bar{h}=\left(\frac{\beta}{1-\beta}\right)\left(\frac{\bar{i}}{1+\pi^{*}} \bar{m}+\overline{t a x}-\frac{\bar{g}}{\bar{e}^{\alpha}}\right) \text {. } \\
& \bar{h}=\bar{b}+\bar{m}+\bar{e}^{1-\alpha} \bar{D}^{g} \text {. } \\
& \bar{e}^{1-\alpha} \bar{D}^{g}=a \bar{b} . \\
& \bar{D}=\bar{D}^{g}+\bar{D}^{p} .
\end{aligned}
$$

Together with equations (56), (58), (59), (61), (64), (65), these equations form a system of 22 equations and 22 unknowns: $\bar{e}, \bar{D}, \bar{D}^{p}, \bar{D}^{g}, \bar{C}, \bar{C}^{T}, \bar{C}^{H}, \bar{Y}^{H}, \bar{I}, \bar{K}, \bar{N}, \bar{m}, \bar{b}, \overline{\operatorname{tax}}, \bar{h}, \bar{q}, \bar{w}, \bar{i}, \bar{i} \bar{i}^{F}, \bar{\varepsilon}, \bar{\pi}^{H}, \bar{\lambda}$. 


\section{Solution Method and Calibration}

The model is solved numerically, based on a log-linearization of the equilibrium conditions of the model around the steady state (stationary relationships are detailed in the appendix). The method of undetermined coefficients was employed; more specifically, Uhlig (1999) methodology was used. Parameters were calibrated in order to match certain characteristics of the Brazilian economy. They are also a range consistent with empirical findings. ${ }^{18}$ Table (1) summarizes the main parameters and steady state ratios corresponding to the baseline specification.

\begin{tabular}{ll}
\hline \hline \multicolumn{2}{l}{ Baseline Specification } \\
\hline \hline$\gamma=0.15$ & CIA parameter \\
$\sigma=1$ & intertemporal elasticity of substitution $=(1 / \sigma)=1$ \\
$\varphi=6$ & elasticity of labor supply $=(1 / \varphi)=0.16$ \\
$\psi=0.75$ & probability of adjusting price at time $\mathrm{t}=0.25$ \\
$\Phi=1.1$ & average mark-up over marginal cost \\
$\theta=0.3$ & capital share in GDP \\
$\alpha=0.6$ & tradables share in consumption \\
$\beta=0.9765$ & subjective discount factor \\
$\pi^{*}=0.06$ & target for annual inflation: $6 \%$ \\
$\mu_{\pi}=2$ & interest rule parameter \\
$\mu_{y}=0.7$ & interest rule parameter \\
$\lambda_{1}=0.12$ & primary surplus rule parameter \\
$\kappa=0.15$ & elasticity of interest rate on foreign loans with respect to $\left(D / D^{*}\right)$ \\
$\rho_{g}=0.70$ & autoregressive coefficient of the Government spending shock \\
$\rho_{\xi}=0.80$ & autoregressive coefficient of the country risk premium shock \\
$\frac{h^{*}}{\overline{G D P}}=0.58$ & public debt to GDP ratio \\
$\left.\frac{\bar{Y}^{H} \bar{B}}{\bar{Y}}=0 . \alpha\right)$ & government foreign debt/domestic debt \\
$\frac{\overline{G D P}}{\overline{\bar{Y}}}=0.72$ & nontradables output/GDP \\
\hline \hline
\end{tabular}

Table 1: Parameters and Steady State Ratios

The model is simulated using optimal policy rule parameters. Those parameters were found by solving the model with different policy parameters combinations and searching for the parameter configuration that minimizes a given loss function that has the unconditional variance of total domestic

\footnotetext{
${ }^{18}$ For example Altonji (1986), Blundell and MaCurdy (1999) and McCallum and Nelson (1999).
} 
output and CPI inflation as its arguments. Table (2) summarizes optimal parameter configuration, for each type of fiscal regime:

\begin{tabular}{llll}
\hline \hline Fiscal Regime/Optimal Parameter Values & $\mu_{\pi}$ & $\mu_{y}$ & \multicolumn{1}{l}{$\lambda_{1}$} \\
\hline Balanced Budget & 2.5 & 1.1 & - \\
Primary Surplus Target Rule & 2.05 & 1.45 & 0.125 \\
\hline \hline Monetary Policy Rule: $i_{t}=\mu_{\pi} \pi_{t}+\mu_{y} y_{t}$ & & & \\
Primary Surplus Rule: $s_{t}=\lambda_{0}+\lambda_{1}\left(h_{t-1}-h^{*}\right)$ & & &
\end{tabular}

Table 2: Optimal Policy Parameters

\section{Dynamic Adjustment to Shocks and the Effect of Different Policy Rules}

Figures (3) and (4) in the appendix display a plot of the impulse responses of selected economic variables to a $1 \%$ shock to government purchases of goods and to the country risk premium.

Before analyzing the effect of each particular shock, it is worth highlighting the most distinguishing difference between the effect of a fiscal shock and a country risk premium shock. Only the latter triggers a significant difference in the path of the tax distortion, across different fiscal rules.

The intuition behind this result is simple. Think about the consequences of a Government spending shock. Since the main source of expenditure increase comes from Government spending on goods and services, the balanced budget and the primary surplus target rule will dictate similar adjustments. This means that the size and the timing of changes in distortionary taxes will be similar and equilibrium allocations will not differ so much.

Consider, alternatively, the effect of any other shock that increases inflation. It prompts the Monetary Authority to raise interest rates, increasing the cost of outstanding debt. Since the pressure on the fiscal accounts comes from temporarily higher interest rate payments, now the two rules dictate a substantially different fiscal adjustment. Under a balanced budget rule, taxes are raised immediately to pay for higher interest payments expenses. Under a primary surplus target rule, the response is more muted: the primary surplus only starts to be increased when the higher cost of outstanding debt significantly increases the stock of public liabilities.

\subsection{Effect of a Government Spending Shock}

I begin by discussing the effect of a government spending shock on the real stock of Government 
liabilities. By definition, this variable is constant under a balanced budget rule, whereas under the primary surplus rule it decreases slightly, as can be seen in Figure (3).

This result may seem counter-intuitive, in light of the increases of Government expenditures, but an explanation is straightforward. When government purchases of goods increases, the primary surplus target rule dictates that taxation should be raised immediately, in order to prevent the primary surplus from falling. This, in turn, prevents the stock of liabilities from increasing. In addition, since Government buys only nontradable goods, the relative price of this goods increases, which means that the real exchange rate tends to appreciate. Since the foreign debt is denominated in units of the tradable good, the cost to service this debt reduces, and this explains the decrease of the net stock of liabilities. The appreciation of the real exchange rate also explains why, on impact, the economy starts running a current account deficit and the aggregate stock of net foreign debt increases.

Overall, the effect of a Government spending shock is significantly smaller than the effect of a country risk premium shock, for a very simple reason: the effect of the fiscal shock on the level of CPI inflation in significantly more mild. In part, this results from the fact that higher Government expenditures in nontradable goods crowds out private consumption of such goods, so overall demand for these goods does not change so much.

\subsection{Effect of a Country Risk Premium Shock}

The country risk premium shock plays an important role in this model (and, in particular, in the selection of optimal parameters) because not only it has a larger impact on inflation dynamics, but also because it triggers substantially different paths of taxation, depending on the fiscal rule that is in place.

Consider the impulse response of the tax distortion $(1-\tau)$, after a $1 \%$ shock in the country risk premium (Figure (4)). The shock translates into a depreciation of the exchange rate (in both nominal and real terms) which prompts the Monetary Authority to raise the interest rate. Under a balanced budget rule, tax rates remain higher, for as long as the interest cost to service public debt is above the steady state level. Note that this cost increases not only because domestic interest rates rose, but also because tradable goods, in which foreign debt is denominated, are now relatively more expensive.

The interpretation of the path of taxation under a primary surplus target rule, in the event of a country risk premium shock, is less straightforward. Tax rates are increased on impact because the tax base decreases, due to the fall of output. A tax rate increase is necessary, therefore, to preserve the level of the primary surplus. However, since the stock of real liabilities falls on impact (due to surprise inflation), then, one period later, the primary surplus rule dictates a decrease in tax 
rates. From this point on, tax rates persist being below their steady state, and slowly adjust to the stationary level. ${ }^{19}$

A consequence of this dynamics is that under a primary surplus rule, the stock of Government liabilities increases significantly after a country risk premium shock. This is the reason why, given this fiscal regime, it is not optimal to have a monetary policy that is very aggressive towards decreasing inflation. Had policy been more restrictive, the volatility of the stock of public liabilities (and therefore of taxation) would be much larger. ${ }^{20}$ The differences in optimal policies implied by different fiscal rules are discussed in the next section.

\section{Macroeconomic Performance under Optimal Policies}

One can think about the implementation of optimal policies in the following way. Under a balanced budget rule, the Fiscal Authority takes as given the increase of the interest cost to service the debt (that happens whenever there is a monetary policy tightening) and adjusts accordingly. The Monetary Authority, in turn, "solves the model" and picks the parameter combination for its Taylor rule that minimizes the loss $L$ given weighted sum of unconditional variance of inflation and output $^{21}$ :

$$
\underset{\mu_{\pi}, \mu_{y}}{\operatorname{Min} L}=\vartheta \operatorname{Var}\left(\pi^{c p i}\right)+(1-\vartheta) \operatorname{Var}(G D P) .
$$

The range of possible parameters is defined in order to ensure the existence and stability of a unique determinate equilibrium, and in accordance with the goal of restricting attention to a policy mix characterized by active monetary policy (hence $\mu_{\pi}$ is strictly larger than 1 ) and passive fiscal policy. ${ }^{22}$ The loss function attaches equal weights to the variance of CPI inflation and GDP, so $\vartheta=0.5$. Later on, this assumption is relaxed, and the shape of the policy frontier is analyzed.

The procedure was to solve the model assuming a balanced budget rule, for all the possible parameter combinations. Then the loss function is computed and the optimal parameter combination

\footnotetext{
${ }^{19}$ Note that this is consistent with the fact that the Government has to raise more tax revenues in order to offset the tendency of the stock of real liabilities to raise. The mechanism that allows this to be achieved without raising tax rates is the fact that the country risk premium shock has a slightly expansionary impact on nontradables output, due to the depreciated exchange rate. As a consequence, one period after the shock the tax base increases. Another factor that decreases the size of the required fiscal adjustement (also present if the rule is a balanced budget) is the fact that, with the RER depreciation, Government purchases become relatively cheaper (measured in units of the composite good).

${ }^{20}$ In fact, the optimal solution comes in the form of a lower $\mu_{\pi}$ and a higher $\lambda_{1}$, but there is no benchmark to compare $\lambda_{1}$, since this parameter is not present in the case of the balanced budget rule.

${ }^{21} \mathrm{~A}$ similar loss function is used by Rudebusch and Svensson (1999).

${ }^{22}$ I search for optimal parameters in the range $\mu_{\pi} \in[1.05 ; 2.5], \mu_{y} \in[0 ; 1.45]$ and $\lambda_{1} \in[0.025 ; 1.5]$, the later being applicable to the case of optimization under a primary surplus target rule.
} 
is identified. As can be seen in Table (1), these parameters are $\mu_{\pi}=2.5$ and $\mu_{y}=1.1$.

Next, I examine optimal parameter choices assuming that the Fiscal Authority implements a primary surplus target rule. In this case, one can think of each Authority moving simultaneously, after having computed $\lambda_{1}, \mu_{\pi}$ and $\mu_{y}$ that solved:

$$
\underset{\lambda_{1}, \mu_{\pi}, \mu_{y}}{\operatorname{Min} L}=\vartheta \operatorname{Var}\left(\pi^{c p i}\right)+(1-\vartheta) \operatorname{Var}(G D P) .
$$

Once again, the procedure was to solve the model using a specific fiscal rule (the primary surplus rule in this case), for all the possible parameters combinations, imposing the restriction that $\lambda_{1}$ is strictly larger than 0.025 , to ensure equilibrium stability and determinacy. Then the loss function is computed, again assuming $\vartheta=0.5$, and the optimal parameter combination is identified. In this case, optimal parameters are $\mu_{\pi}=2.05$ and $\mu_{y}=1.45$ and $\lambda_{1}=0.125$

Table (3) summarizes the variance of certain key economic variables, under alternative scenarios about the fiscal rules and the corresponding optimal policy parameters. Results in Table (3) show that a primary surplus target rule delivers significantly better economic performance, measured by the loss function.

Moreover, under both types of fiscal regimes, but especially under a balanced budget rule, optimal policy entails a strong reaction of monetary policy with respect to increases in inflation (captured in a high value for $\mu_{\pi}$, a result that is typical of the literature on optimal monetary policy in the presence of nominal rigidities.

It is interesting, however, to note that optimal monetary policy under a primary fiscal rule is less restrictive. This reason is that, under a primary surplus rule, increased expenditures on public debt interest payments are not immediately compensated by a higher surplus. Therefore, if the increase in interest payments is high (case of a policy that reacts strongly to increases in inflation), there is a chance that a primary surplus rule will result in a larger required fiscal adjustment (because the adjustment is not done fast enough).

Finally, the conclusion regarding the better performance of the primary surplus rule is robust to changes in the underlying assumption concerning the degree of capital mobility. The sensitivity analysis performed consisted in increasing the parameter $\kappa$, which measures the elasticity of the interest rate charged on foreign loans to variations in net external debt. Recall that the larger $\kappa$ is, the steeper is the (upward sloping) supply of foreign funds. In other words, there is less capital mobility in the sense that foreign investors require a larger premium to increase the share of these bonds in their portfolio.

The ranking of optimal policies does not change, but the level of variance of the variables in question is much smaller. The reason is that, in this smaller capital mobility scenario, there are forces in action that trigger a faster adjustment to the steady state. In the case of the country risk premium shock, the sudden depreciation of the nominal exchange rate generates a trade surplus and 
a corresponding decrease in net foreign debt. This, in turn, translates into a tendency of nominal exchange rate to appreciate, given that the lower level of foreign debt tends to reduce the interest rate charged on foreign loans.

Another important feature to notice is the significant change in optimal policy parameters, especially in the case of the balanced budget rule. Optimal policy is significantly less active (captured by lower values of $\mu_{\pi}$ and $\mu_{y}$ ), which is not surprising, given that under this scenario there are stronger market adjustment channels forcing the economy back to the steady state. This translates into a decreased need for policy intervention.

The case of the parameter capturing the response to output deviations is particularly striking, since it drops to a level close to zero, even in the presence of high pass-through. This finding is in line with the conclusions drawn by Schmitt-Grohé and Uribe (2004a), who showed, in a closed economy model, that under different scenarios for the fiscal rules, it is optimal not to react to output deviations. The findings in this paper show, therefore, that this conclusion is closely related to underlying assumptions concerning the degree of capital mobility.

Interestingly, the conclusion that the response to output deviations should be more muted does not carry over to the case of a primary fiscal rule. A plausible explanation is given by the fact that, in the model, a country risk premium shock has a subsequent expansionary effect on nontradables output (because of the expenditure switching effect). A balanced budget rule curbs part of this tendency, since taxes are raised immediately. Under a primary surplus target rule, this mechanism is not present and hence nontradables output tends to be more volatile, which justifies a higher response of interest rates with respect to output deviations. If this model had been designed and calibrated in such a way that the expenditure switching effect was more mild (or less fast) ${ }^{23}$, then the conclusion that the response to output should be muted would probably carry over to the case of the primary surplus target.

Next, I turn to the question of whether it is optimal to target a domestic measure of inflation (that is not affected so much by the price of tradable goods), as opposed to targeting the CPI. This is a conclusion typically reached in the literature on optimal monetary policy in open economies with nominal rigidities and high pass-through. ${ }^{24}$

The model is solved by assuming that the Monetary Authority implements the following rule:

$$
\widehat{i}_{t}=\mu_{\pi} \widehat{\pi}_{t}^{h}+\mu_{y} \widehat{y}_{t},
$$

where $\pi^{h}$ denotes inflation in the nontradables sector and "hats" indicate percentage deviation from

\footnotetext{
${ }^{23}$ This could be done with smaller pass-through.

${ }^{24}$ The intuition is the following. With high pass-through, CPI inflation tends to be more volatile, so to stabilize the nominal exchange rate is a way to prevent this outcome. However, stabilizing the nominal exchange rate prevents the expenditure switching effect, which otherwise would have decreased the volatility of output.
} 
steady state levels. Optimal parameters are found by solving (66) and (67) once again, with the exception that the unconditional variance of nontradables inflation replace the unconditional variance of CPI inflation in the loss function.

Results are reported in Table (4). The volatility of economic variables is significantly smaller, suggesting that this model yields the same conclusion of the existing literature, in the sense that, in environments with high degree of pass-through, the economy is better-off if policymakers try to minimize the volatility of an inflation index that does not depend so much on movements of the exchange rate. The ranking of policies does not change and, overall, optimal parameters are similar to the ones previously found. 


\begin{tabular}{|c|c|c|c|c|c|}
\hline $\begin{array}{l}\text { SCENARIOS } \\
\text { (Inflation target is CPI) }\end{array}$ & LOSS & CPI & GDP & $\begin{array}{l}\text { Hours } \\
\text { Worked }\end{array}$ & Consumption \\
\hline \multicolumn{6}{|c|}{ A. BASELINE SCENARIO } \\
\hline \multicolumn{6}{|l|}{ Case 1a: } \\
\hline \multicolumn{6}{|l|}{ Optimal Policy under } \\
\hline \multicolumn{6}{|l|}{ Balanced Budget Rule } \\
\hline$\mu_{\pi}=2.5$ & 0.1377 & 0.0899 & 0.1855 & 0.5328 & 0.4515 \\
\hline \multicolumn{6}{|l|}{$\mu_{y}=1.1$} \\
\hline \multicolumn{6}{|l|}{ Case 2a: } \\
\hline \multicolumn{6}{|l|}{ Optimal Policy under } \\
\hline \multicolumn{6}{|l|}{ Primary Surplus Target } \\
\hline$\mu_{\pi}=2.05$ & 0.0923 & 0.1002 & 0.0844 & 0.3367 & 0.4434 \\
\hline \multicolumn{6}{|l|}{$\mu_{y}=1.45$} \\
\hline \multicolumn{6}{|l|}{$\lambda_{1}=0.125$} \\
\hline \multicolumn{6}{|c|}{ B. SENSITIVITY ANALYSIS } \\
\hline \multicolumn{6}{|c|}{ (Less Capital Mobility $k=1$ ) } \\
\hline \multicolumn{6}{|c|}{ Case 1b: } \\
\hline \multicolumn{6}{|l|}{ Optimal Policy under } \\
\hline \multicolumn{6}{|l|}{ Balanced Budget Rule } \\
\hline$\mu_{\pi}=1.4$ & 0.0303 & 0.0165 & 0.0440 & 0.0858 & 0.0663 \\
\hline \multicolumn{6}{|l|}{$\mu_{y}=0.15$} \\
\hline \multicolumn{6}{|l|}{ Case 2b: } \\
\hline \multicolumn{6}{|l|}{ Optimal Policy } \\
\hline \multicolumn{6}{|l|}{ Primary Surplus Target } \\
\hline$\mu_{\pi}=2.1$ & 0.0147 & 0.0158 & 0.0137 & 0.0543 & 0.0625 \\
\hline \multicolumn{6}{|l|}{$\mu_{y}=1.45$} \\
\hline$\lambda_{1}=0.325$ & & & & & \\
\hline
\end{tabular}

Table 3: Variance of Selected Economic Variables Under Alternative Fiscal Rules and Optimal Policy Parameters 


\begin{tabular}{|c|c|c|c|c|c|}
\hline $\begin{array}{l}\text { SCENARIOS } \\
\text { (Inflation Target is Domestic Inflation) }\end{array}$ & LOSS & $\begin{array}{l}\text { Domestic } \\
\text { Inflation }\end{array}$ & GDP & $\begin{array}{l}\text { Hours } \\
\text { Worked }\end{array}$ & Consumption \\
\hline \multicolumn{6}{|l|}{ A. BASELINE SCENARIO } \\
\hline \multicolumn{6}{|l|}{ Case 1a: } \\
\hline \multicolumn{6}{|l|}{ Optimal Policy under } \\
\hline \multicolumn{6}{|l|}{ Balanced Budget Rule } \\
\hline$\mu_{\pi}=2.5$ & 0.0278 & 0.0016 & 0.054 & 0.0268 & 0.2747 \\
\hline \multicolumn{6}{|l|}{$\mu_{y}=0.15$} \\
\hline \multicolumn{6}{|l|}{ Case 2a: } \\
\hline \multicolumn{6}{|l|}{ Optimal Policy } \\
\hline \multicolumn{6}{|l|}{ Primary Surplus Target } \\
\hline$\mu_{\pi}=2.5$ & 0.0023 & 0.0006 & 0.004 & 0.0044 & 0.3060 \\
\hline \multicolumn{6}{|l|}{$\mu_{y}=0.8$} \\
\hline \multicolumn{6}{|l|}{$\lambda_{1}=0.225$} \\
\hline \multicolumn{6}{|l|}{ B. SENSITIVITY ANALYSIS } \\
\hline \multicolumn{6}{|l|}{ (Less Capital Mobility $k=1$ ) } \\
\hline \multicolumn{6}{|l|}{ Case 1b: } \\
\hline \multicolumn{6}{|l|}{ Optimal Policy under } \\
\hline \multicolumn{6}{|l|}{ Balanced Budget Rule } \\
\hline$\mu_{\pi}=2.5$ & 0.0124 & 0.003 & 0.0246 & 0.0075 & 0.0381 \\
\hline \multicolumn{6}{|l|}{$\mu_{y}=0.05$} \\
\hline \multicolumn{6}{|l|}{ Case 2b: } \\
\hline \multicolumn{6}{|l|}{ Optimal Policy under } \\
\hline \multicolumn{6}{|l|}{ Primary Surplus Target } \\
\hline$\mu_{\pi}=2.5$ & 0.0008 & 0.0003 & 0.0014 & 0.0451 & 0.0017 \\
\hline \multicolumn{6}{|l|}{$\mu_{y}=0.9$} \\
\hline$\lambda_{1}=0.375$ & & & & & \\
\hline
\end{tabular}

Table 4: Variance of Selected Economic Variables Under Alternative Fiscal Rules and Optimal Policy Parameters 


\section{Minimum Variance Policy Frontiers}

The results discussed so far reflect the underlying hypothesis that the volatility of inflation and total domestic output receive the same weight in the loss function $(\vartheta=0.5)$.It would be interesting to analyze whether conclusions might change if different weights were assign to each term of the loss function.

In order to answer this question, efficient policy frontiers were built. The procedure amounts to solving the model using all possible combinations of policy parameters comprised in the range described in (66) and (67). Then, for a given weight $\vartheta$, the parameter combination that yields the minimum loss is selected and the associated variances of CPI inflation and output are stored. The procedure is repeated for several different values of $\vartheta$, given that $\vartheta \in[0,1]$ and then a plot of all the minimum variance CPI/GDP combinations form an efficient policy frontier.

Figures (1) and (2) depict the minimum variance policy frontier corresponding to the baseline scenario (imperfect but high capital mobility, low $\kappa$ ) and to the sensitivity analysis exercise (lower capital mobility), respectively. The shape of the policy frontier reinforces the finding that a primary surplus target rule yields superior results.

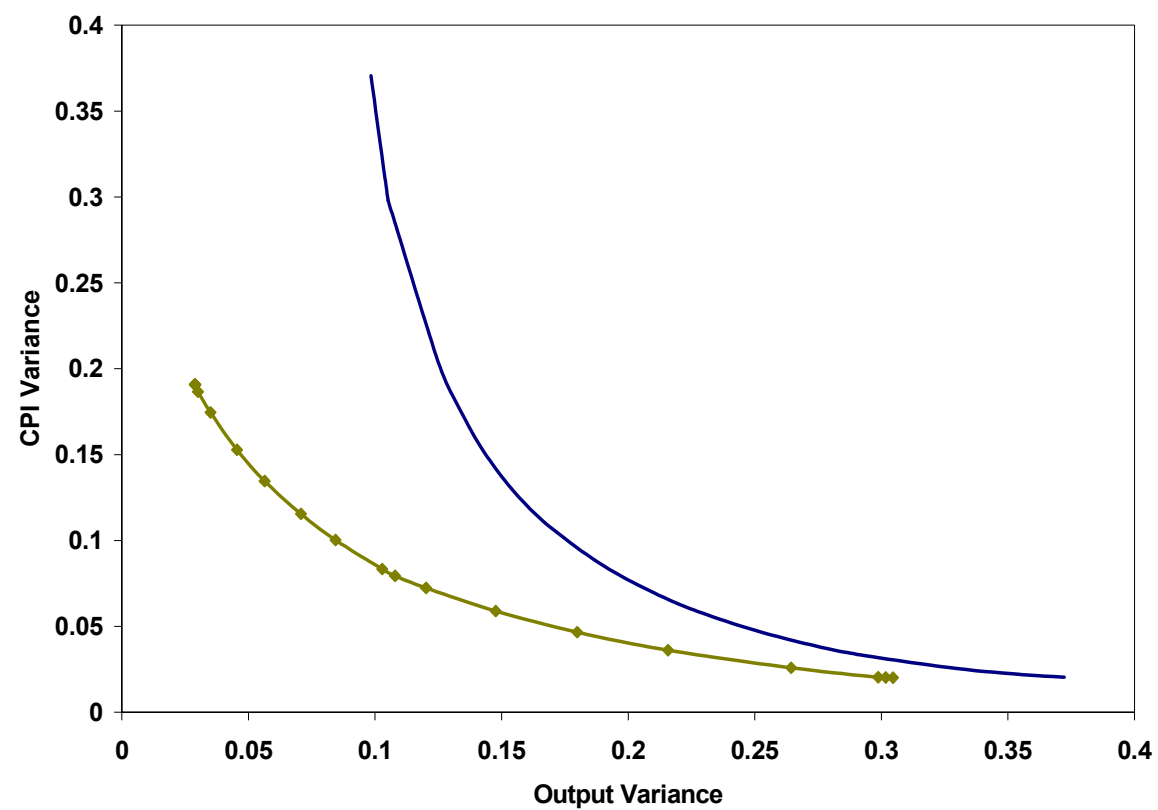

Figure 1: Efficient Policy Frontier (Baseline Scenario). Solid line: policy frontier under a balanced budget rule. Dotted line: policy frontier under a primary surplus rule. 


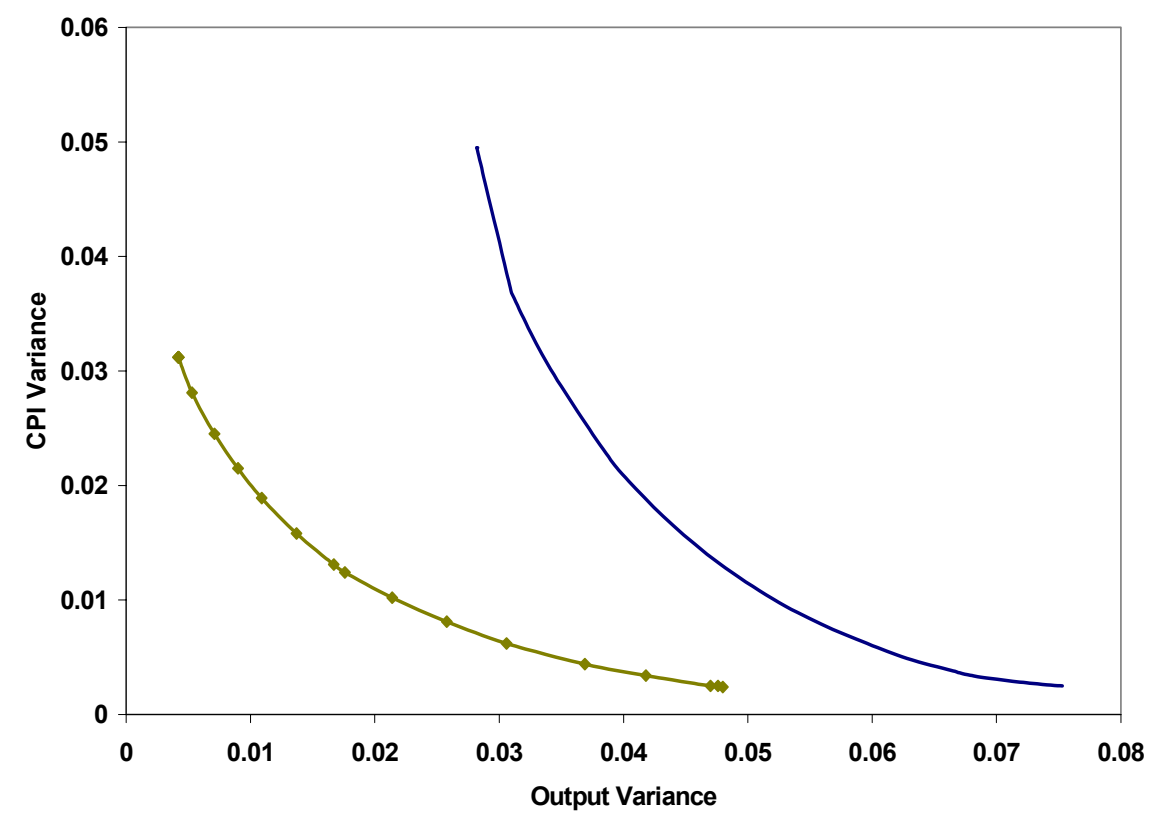

Figure 2: Efficient Policy Frontier (Sensitivity analysis, lower capital mobility). Solid line: policy frontier under a balanced budget rule. Dotted line: policy frontier under a primary surplus rule.

\section{Concluding Remarks}

This paper studies monetary and fiscal policy rules, and investigates the characteristics of optimal policies. The central focus of the paper is on the implications of different fiscal regimes, an issue that is examined using a dynamic stochastic general equilibrium framework, that describes an open economy, with capital accumulation and imperfect capital mobility.

The main findings of this research can be summarized as follows. First, the characteristics of optimal monetary policy clearly depend on the underlying fiscal regime. The response of the interest rate with respect to increases in inflation should be less strong (implying the acceptance of higher inflation volatility) if the fiscal policy is characterized by a target for the primary surplus. This conclusion is particularly relevant, given the fact this rule delivers superior economic performance, when compared to the one under a balanced budget rule.

The requirement that monetary policy should be less restrictive can be interpreted in light of the fact that the primary surplus rule does not dictate an (immediate) fiscal adjustment when the cost of servicing the public debt increases. Therefore, if monetary policy is very restrictive and significantly increases the cost of outstanding debt, a primary surplus rule may result in a very volatile stock of 
public liabilities.

The optimality of the primary surplus rule holds for the whole spectrum of weights that can be attached to the (weighted) sum of unconditional variances of inflation and output. The efficient policy frontier associated to the presence of a primary surplus target is clearly superior, delivering smaller levels of variance for both variables. One way to interpret this result is that a primary surplus rule renders a fiscal regime that is less procyclical than that associated to a balanced budget rule. However, the primary surplus rule will only deliver good economic performance if the primary surplus target is increased sufficiently fast, to prevent large increases in the stock of public liabilities.

Second, the specific way the economy performs under alternative fiscal rules depends fundamentally on the type of shock that is being considered. Shocks that affect the fiscal accounts through the cost of outstanding debt are the ones that have the potential to trigger different responses of taxation, depending on the specific rule adopted. Therefore, it is of utmost importance in this research agenda to model properly the nature of shocks, otherwise the comparison of fiscal rules is simply not very informative, given that they will say little about differences in the path of taxation, implied by distinct fiscal regimes.

Finally, the conclusion that fiscal adjustments dictated by a primary surplus rule are beneficial for macroeconomic performance is robust to changes in some parameters of the model. Although the assumption concerning capital mobility does, indeed, affect the level of the variance of the economic variables, it does not affect conclusions about the ranking of desirable fiscal-monetary regimes. It does have an effect, though, on optimal policy parameters, depending on the kind of fiscal regime that is in place. Under a balanced budget for instance, the assumption of low capital mobility suffices to the generate the "closed economy" result that optimal monetary policy features a muted response to output fluctuations (even maintaining the assumption of high pass-through). In contrast, with a primary surplus rule, the optimality of a strong response to output fluctuations does not depend on any particular assumptions concerning the degree of capital mobility.

This paper departed from the point of view that, despite the widespread consensus concerning the importance of monetary and fiscal discipline, there is still a lot to learn in terms of the consequences of particular policy mixes and the characteristics of optimal policies. There is a number of directions in which this research should be further developed, such as the possibility of reallocation of production inputs between tradables and nontradable sector, and the corresponding introduction of an endogenous level of tradable output. Overall, this research showed that the introduction of open economy elements changes conclusions previously reached by models that either abstract from international trade of goods/bonds, or that do not explore the implications of distortionary taxation and specific numerical constraints imposed to the performance of the fiscal accounts. 


\section{Appendix}
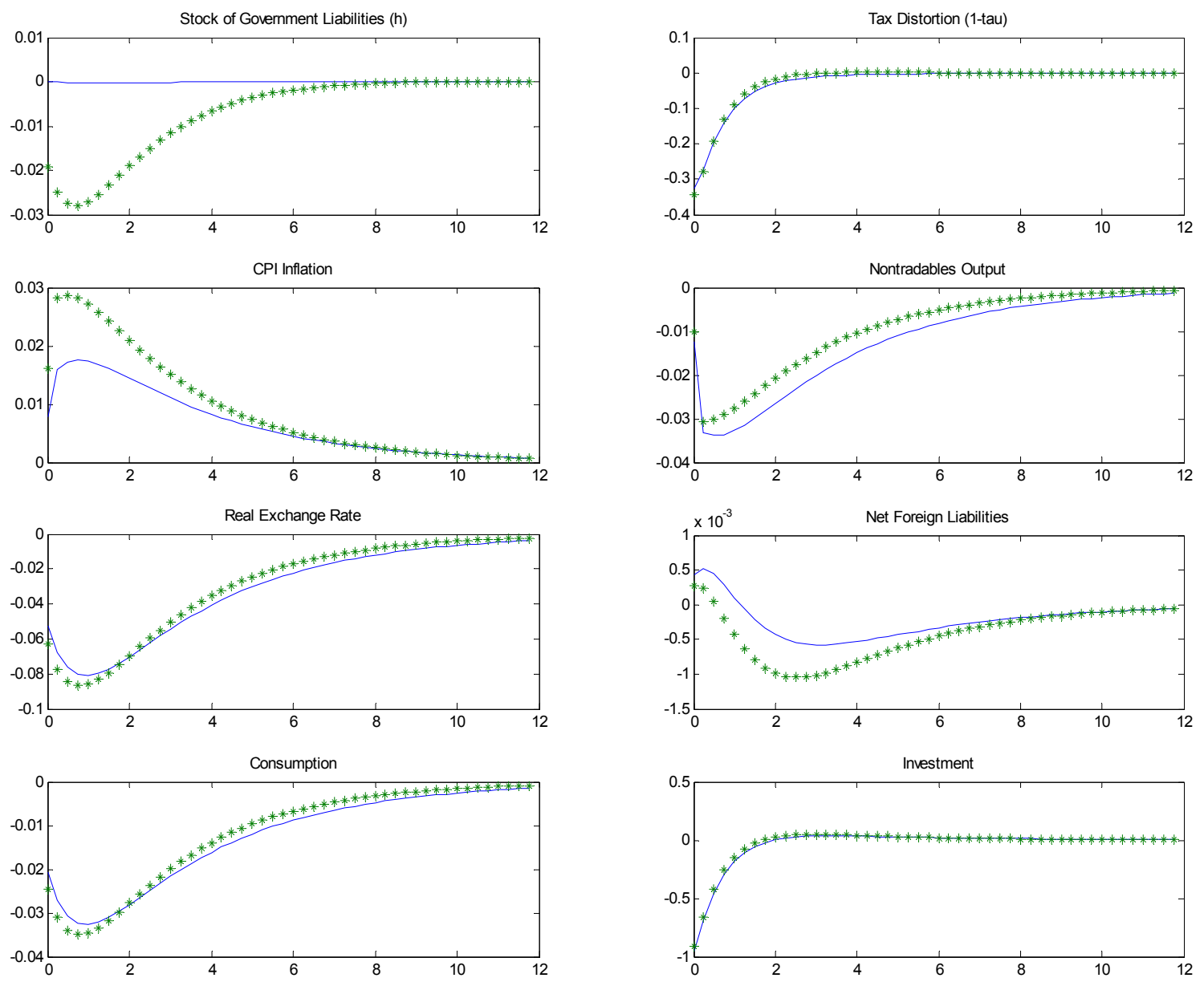

Figure 3: Impulse Response to a 1\% shock to government expenditures. Solid line: response under a balanced budget rule. Dotted line: response under a primary surplus target rule 

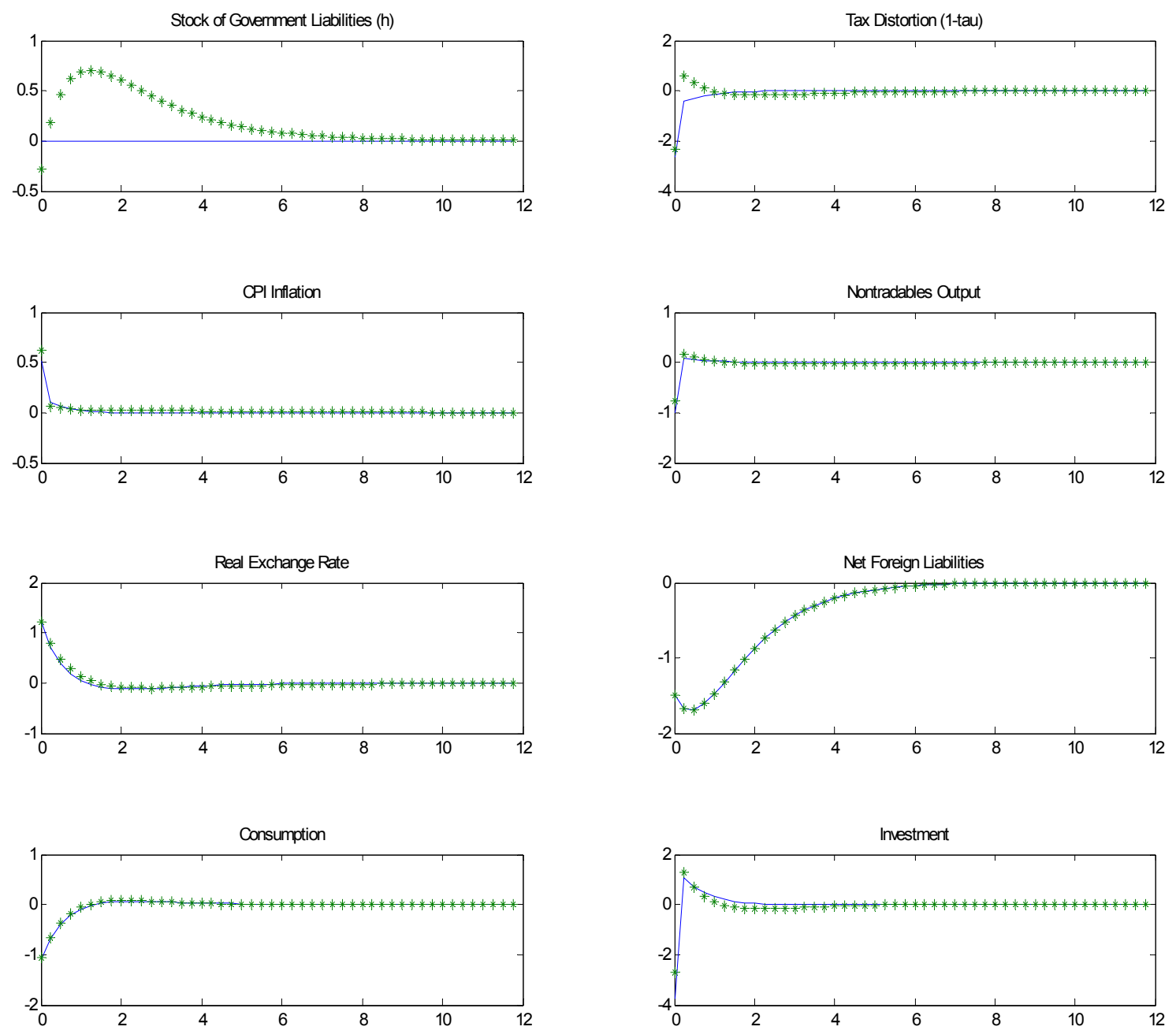

Figure 4: Impulse Response to a $1 \%$ shock to country risk premium. Solid line: response under a balanced budget rule. Dotted line: response under a primary surplus target rule 


\section{References}

[1] Altonji, J. (1986), "Intertemporal Substitution in Labor Supply: Evidence from Micro Data", Journal of Political Economy 94(3) part 2, pp. S176-S215.

[2] Annicchiarico, B., Marini G. and Piergallini, A. (2004), "Monetary Policy and Fiscal Rules", CEIS Tor Vergata Research Paper Series 50.

[3] Bénassy, J-P. (2003), "Fiscal Policy and Optimal Monetary Rule in a Non-Ricardian Economy", Review of Economic Dynamics, 6, 498 - 512.

[4] Blundell, R. and MaCurdy, T. (1999), "Labor Supply: A Review of Alternative Approaches", in Aschenfleter and Card (eds), Handbook of Labor Economics 3A, Elsevier Science, Amsterdam.

[5] Calvo, G. A. (1983), "Staggered Prices in a Utility-Maximizing Framework", Journal of Monetary Economics 12(3), pp. 383 - 398.

[6] Canzoneri, M. (2002), "Notes on Monopolistic Competition and Nominal Inertia", mimeo.

[7] Canzoneri, M., Cumby, R. and Diba, B. (2002), "Should the European Central Bank and the Federal Reserve Be Concerned About Fiscal Policy?", paper presented at the Federal Reserve Bank of Kansas City's symposium on "Rethinking Stabilization Policy" at Jackson Hole, August $29-31,2002$.

[8] Canzoneri, M., Cumby, R. and Diba, B. (2004), "Macroeconomic Policy in the European Monetary Union", paper presented at the NBER's ISOM in Reykjavik, Iceland, June 18-19, 2004.

[9] Correia, I., Nicolini, J.P. and Teles, P. (2002), "Optimal Fiscal and Monetary Policy: Equivalence Results", Federal Reserve Bank of Chicago, 2002 Working Paper N ${ }^{o} 16$.

[10] Devereux, M., Lane, P. and Xu, J. (2004), "Exchange Rates and Monetary Policy in Emerging Market Economies", Institute for International Integration Studies, Trinity College Dublin, Discussion Paper $\mathrm{n}^{\circ} 36$.

[11] Erceg, C.J., Henderson, D.W. and Levin, A.T. (2000), "Optimal Monetary Policy with Staggered Wage and Price Contracts", Journal of Monetary Economics, 46 (2000), pp. 282 - 313.

[12] Goodfriend, M. and King, R. (1997) "The New Neoclassical Synthesis and The Role of The Monetary Policy", NBER Macroeconomics Annual, Cambridge, MA, 1997, pp. 231-282.

[13] King, R. and Wolman, A. (1999), "What Should the Monetary Authority Do When Prices are Sticky?", in: Taylor, J. (Ed.), Monetary Policy Rules, The University of Chicago Press, Chicago, 
[14] Kollmann, R. (2002), "Monetary Policy Rules in the Open Economy: Effects on Welfare and Business Cycles", Journal of Monetary Economics, 49 (2002), pp. 989 - 1015.

[15] Kollman, R. (2004), "Welfare Maximizing Operational Monetary and Fiscal Policy Rules", mimeo, Department of Economics, University of Bonn.

[16] Leeper, Eric M. (1991), "Equilibria Under 'Active' and 'Passive' Monetary and Fiscal Policies", Journal of Monetary Economics 27 (1), pp. 129 - 147.

[17] Leith, C and Wren-Lewis, S (2000), "Interactions Between Monetary and Fiscal Policy", Economic Journal, 110, pp. 93-108.

[18] McCallum,B. and Nelson, E. (1999), "Performance of Operational Policy Rules in an Estimated Semiclassical Structural Model", in: John Taylor (editor) Monetary Policy Rules, , The University of Chicago Press, Chicago.

[19] Obstfeld, M. and Rogoff, K. (1998), "Foundations of International Macroeconomics", Cambridge, Mass. MIT Press.

[20] Rotemberg, J.J. and Woodford. M. (1999), "Interest Rate Rules in an Estimated Sticky Price Model", in: Taylor, J. (Editor), Monetary Policy Rules, The University of Chicago Press, Chicago.

[21] Rudebusch, G. and Svensson, L. (1999), "Policy Rules for Inflation Targeting", in: Taylor, J. (Editor), Monetary Policy Rules, The University of Chicago Press, Chicago.

[22] Schmitt-Grohé, S. and Uribe, M. (2003), "Closing Small Open Economy Models", Journal of International Economics, 61(1), October 2003, pp. 163 - 185.

[23] Schmitt-Grohé, S. and Uribe, M. (2004a), "Optimal, Simple, and Implementable Monetary and Fiscal Rules", NBER Working Paper Series, Working Paper 10253, January 2004.

[24] Schmitt-Grohé, S. and Uribe, M. (2004b), "Optimal Fiscal and Monetary Policy Under Sticky Prices", Journal of Economic Theory, 114 (February 2004), pp. 198 - 230.

[25] Siu, H. (2004), "Optimal Fiscal and Monetary Policy with Sticky Prices", Journal of Monetary Economics, 51(3) April 2004, pp. 575 - 607.

[26] Taylor, J. (1993), "Discretion versus Policy Rules in Practice", Carnegie-Rochester Conference Series on Public Policy, Vol. 39, pp. 195 - 214. 
[27] Uhlig, H. (1999), "A Toolkit for Analyzing Nonlinear Dynamic Stochastic Models Easily", in: Marimon, R. and Scott, A. (Eds.), Computational Methods for the Study of Dynamic Economies. Oxford University Press, Oxford, pp.30-61. 